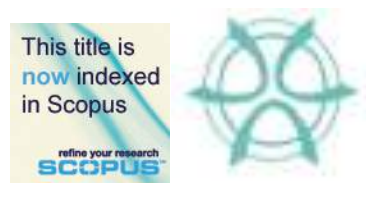

PLANNING MALAYSIA:

Journal of the Malaysian Institute of Planners

SPECIAL ISSUE IV (2016), Page 75 - 86

\title{
COMMUNITY PERCEPTION OF MANAGEMENT GOALS IN MATOUSHAN NATIONAL NATURE RESERVE
}

\author{
Chengzhao Wu ${ }^{1}$, Tianren Yang ${ }^{2}$, Pei Pei ${ }^{3} \&$ Haisu Chen ${ }^{4}$ \\ 1,2,3 College of Architecture and Urban Planning \\ TONGJI UNIVERSITY, SHANGHAI, CHINA.
}

\begin{abstract}
National nature reserve (NNR) is the important ecological baseline of the ecosystem security of the country. However, it is under the pressure of mass tourism, low participation of local community, and improper management. It is a matter of great urgency to determine strategies and tools in support of the balance between conservation and development of NNR. At present, the management system of NNR in China is a system where the country supervises and the local government manages. The perception of the NNR's management aim has direct influence on the management efficiency and protection effect. In this paper, the issue with Matoushan National Nature Reserve in Jiangxi Province has been analyzed as an example. Local residents and administrators' attitudes and perceptions of the management goals of the NNR were measured from three aspects: (1) response to current policies practiced in the reserve; (2) degrees of perception of community co-management; (3) expectation for future development of the reserve. Based on the measurement of community attitude and intention toward four dimensions of ecotourism and assessment of the values and current threats to Matoushan NNR, five sustainable development strategies have been put forward which involve ecological conservation and recovery, local culture revitalization, industry and program planning, educational tourism planning, and periphery development and management. Seeing the resources inside the reserve areas as a natural, cultural, social and economic asset, ecotourism planning is holistic by integrating the goals of natural resources conservation and those of social and economic improvement in revitalizing and managing NNR.
\end{abstract}

Keyword: Community Perception, Management Goal, National Nature Reserve, Planning Methodology, Sustainable Development

\section{INTRODUCTION}

Since the nature reserve is in a long-term interdependence relation with residents of neighborhood, the support from local residents is directly related to the proper management of it. By stakeholders analysis, including those who affect or are affected by a decision or an action (Freeman, 1984), implementation and assessment of outcomes will be improved (Grimble \& Wellard, 1997). There are about 30 to 60 million people live in and around China's reserves (D. Q. Zhou \& Edward Grumbine, 2011). Since, society and landscape are the result of a dynamic exchange process between the individuals and their 
Chengzhao Wu, Tianren Yang, Pei Pei \& Haisu Chen

Community Perception of Management Goals in Matoushan National Nature Reserve

environment, a sustainable landscape development should guarantee that the residents can participate in their everyday landscape (Buchecker et al., 2003).

Since the 1970s, many researchers and international organizations have devoted to the topic on how to coordinate relation between a nature reserve and neighborhood residents and come up with a series of coordination mechanism, such as the concept of biosphere reserve (Price, 2002; Price et al., 2010; Reed \& Egunyu, 2013), comprehensive protection and development projects, and community co-management. All of them are common in that both of protection and development are included into functions of a nature reserve. As with management, they stress community participation and represent fairness and respect to local residents.

Currently, China remains at primary stage regarding construction and management of nature reserves. Though the number of nature reserves is being extended quickly, the improvement of quality is relatively lagging behind (D. Zhou et al., 2014). Community residents and managers, as objects and primary participants of conservation area management(Grimble \& Wellard, 1997), will directly affect the implementation effect of nature reserve policies. Koorosh et al. (2015) proposed a indicator-based approach for the subjective evaluation of participation including the process and the outcome. This paper, by taking Matoushan National Nature Reserve as a case, analyzed community residents' and managers' perception of management aim in order to: (1) identify the differences between the community residents and managers' response to nature reserve policies; (2) analyze the key factors that affect the relation between community and NNR; (3) discuss effective ways for improving the relation.

\section{RESEARCH METHODS}

Through literature analysis, field investigation, questionnaire survey, conversation with managers, and expert interview, this paper has made a primary research of community perception of the goals of nature reserve management. The research data are attained through a questionnaire survey and objects of the survey are social residents who are above 18 in Matoushan NNR and managers of local Agricultural Bureau, Forestry Bureau and Land Resources Bureau. Content of the questionnaire is consisting of three parts: (1) response to current policies practiced in the reserve; (2) degrees of perception of community co-management; (3) expectation for future development of the reserve.

As with the questions, there are closed and open questions: the closed questions facilitate the attainment of data for statistical research and analysis of cognition attitudes of community residents and managers towards the reserve. Collection of data of this research was completed in March of 2013. In total, 31 effective questionnaires were attained (8 are manager questionnaires). The site of community resident survey was in a house of peasant household while that of manager survey was in local government department. Data processing was completed by making use of frequencies, descriptive, cross tables, independent-samples T test module of SPSS 19.0 software. 


\section{RESEARCH FINDINGS}

\section{Response to Current Policies in the Reserve \\ More than half of the residents are not benefiting from, and unsatisfied with the current policies}

Grimble and Wellard (1997) implied that natural resource always have multi-users who are not be compatible, taking forest and tree resources as example. According to the survey of satisfaction with current policies in the nature reserve, $13.0 \%$ of the community residents are satisfied with current policies, $65.2 \%$ of the residents have not benefited from and got damaged by current policies and $21.7 \%$ of the residents think use restrictions on lumbering have caused great influence on their life and show dissatisfaction. On the other hand, managers primarily hold positive or neutral attitude towards current policies. After natural resources with protective value are included into the reserve according to relevant laws and regulations, some original sources of production and life of community residents are cut off. Though community residents can directly or indirectly have some incomes through participating in ecological agriculture and tourism operation after the establishment of the reserve, the major income of the nature reserve is still in general attained by external public, which consequently generate passive mood towards the reserve in the community.

\section{Life problems like poor living conditions and employment difficulty are prevailing among the residents}

Table 1: Current living states of community residents

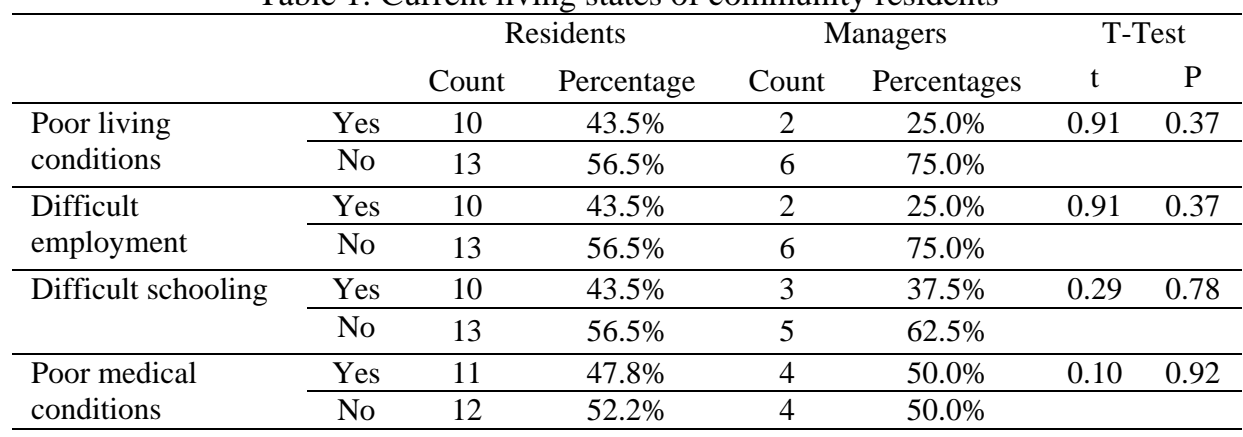

So far as current living state concerned, the community residents are holding different attitudes towards living conditions, employment issue, schooling issue and medical conditions (Table 1). In the process of the survey, the author discovered that the traffic for residents living in Matoushan, Gangxi village and Gangbian village is inconvenient; moreover, the residents generally said that the schooling is difficult and the medical conditions are poor. As a matter of fact, those problems are universal in all nature reserves in China. The community residents are living in rural mountain areas and the living conditions there are poor. Besides that, the roads to natural villages in the reserve are primarily dirt roads, and as a result of which, traffic is inconvenient and material 
Chengzhao Wu, Tianren Yang, Pei Pei \& Haisu Chen

Community Perception of Management Goals in Matoushan National Nature Reserve

circulation is difficult. All of above have largely restricted economic development of the reserve and surrounding communities and caused much inconvenience for the residents.

Most residents hope to improve life through tourism development of the reserve which may provide more jobs

Table 2: Future policy preferences

\begin{tabular}{lccccccc}
\hline & & \multicolumn{2}{c}{ Residents } & \multicolumn{2}{c}{ Managers } & \multicolumn{2}{c}{ T-Test } \\
\cline { 3 - 8 } & & Count & Percentage & Count & Percentages & $\mathrm{t}$ & $\mathrm{P}$ \\
\hline Provide jobs & Yes & 12 & $52.2 \%$ & 5 & $62.5 \%$ & 0.49 & 0.63 \\
& No & 11 & $47.8 \%$ & 3 & $37.5 \%$ & & \\
\hline Promote tourism & Yes & 19 & $82.6 \%$ & 7 & $87.5 \%$ & 0.31 & 0.76 \\
development & No & 4 & $17.4 \%$ & 1 & $12.5 \%$ & & \\
\hline Improve & Yes & 4 & $17.4 \%$ & 3 & $37.5 \%$ & 1.16 & 0.26 \\
education & No & 19 & $82.6 \%$ & 5 & $62.5 \%$ & & \\
\hline Provide technical & Yes & 3 & $13.0 \%$ & 5 & $62.5 \%$ & 3.06 & $<0.01$ \\
training & No & 20 & $87.0 \%$ & 3 & $37.5 \%$ & & \\
\hline Farmland & Yes & 2 & $8.7 \%$ & 1 & $12.5 \%$ & 0.30 & 0.76 \\
improvement & No & 21 & $91.3 \%$ & 7 & $87.5 \%$ & & \\
\hline
\end{tabular}

According to an analysis of the residents' future life development policies, promoting tourism development $(\mathrm{t}=0.31, \mathrm{p}=0.76)$ and providing jobs $(\mathrm{t}=0.49, \mathrm{p}=0.63)$ are very important to promote development of the reserve from perspectives of both residents and managers. On the other hand, the limited farmland is difficult to meet settlement of family labors and improvement of economic conditions. Both parties agree that farmland improvement is high in cost while limited in development potential. Consequently, they are holding negative attitude towards farmland improvement $(\mathrm{t}=0.30, \mathrm{p}=0.76)$.

In terms of providing technical training, the managers and community residents are varying in idea $(\mathrm{t}=3.06, \mathrm{p}<0.01)$. The community residents, who are not interested in technical training in the level of development policies, hope the managers will directly provide economic benefits so as to promote development of the reserve.

\section{Degrees of Perception of Community Co-management}

More than half of the residents have no idea of community co-management while the managers have a higher degree of perception

Table 3: Perception of community co-management

\begin{tabular}{|c|c|c|c|c|c|}
\hline & & Do not know & $\begin{array}{c}\text { Have heard } \\
\text { of it but do } \\
\text { not } \\
\text { understand }\end{array}$ & $\begin{array}{c}\text { Know but do } \\
\text { not care }\end{array}$ & $\begin{array}{l}\text { Know and } \\
\text { participate }\end{array}$ \\
\hline \multirow[t]{2}{*}{ Residents } & Count & 15 & 4 & 3 & 1 \\
\hline & Percentage & $65.2 \%$ & $17.4 \%$ & $13.0 \%$ & $4.3 \%$ \\
\hline \multirow[t]{2}{*}{ Managers } & Count & 2 & 3 & 2 & 1 \\
\hline & Percentage & $25.0 \%$ & $37.5 \%$ & $25.0 \%$ & $12.5 \%$ \\
\hline
\end{tabular}


Community residents' and managers' degrees of perception of community comanagement are shown in Table 3. As with knowledge related to community comanagement and its specific significance, $4.3 \%$ of the residents know it and will participate in actively, $13.0 \%$ of the residents know but do not care while $65.2 \%$ of the residents do not know it. In comparison, the managers have a higher degree of cognition of community co-management (mean equation $\mathrm{t}$ test: $\mathrm{t}=-2.53, \mathrm{df}=30, \mathrm{Sig} .=0.017, \mathrm{p}<0.05$ ), with $25.0 \%$ of the managers knowing but do not care it and $12.5 \%$ of the managers knowing it and will actively participate in it. Policies on community participation need to be further promoted among community residents.

\section{The community residents care more about development and improvement of life while the managers care more about continuity of traditional industry culture.}

In the community co-management part of the questionnaire, four questions (planting industry, breeding industry, ecological tourism industry, and hydropower and transportation industry) are presented to know the residents' and managers' attitudes towards key development projects and aiding projects. In it, "the most important" is rated 5 points, "relative important" 4 points, "common" 3 points, "less important" 2 points and "not important" 1 point; an average mean of Likert scale that lies between 3.5 and 5 means important, between 2.5 and 3.4 means common and between 1 and 2.4 means not important. Analysis result of the survey data is shown as following

Table 4: Residents' preferences of key development projects regarding community comanagement

\begin{tabular}{ccccccccc}
\hline Project Content & \multicolumn{3}{c}{ Residents } & \multicolumn{3}{c}{ Managers } & \multicolumn{2}{c}{ T-Test } \\
\cline { 2 - 9 } & Mean & $\begin{array}{c}\text { Std. } \\
\text { Dev }\end{array}$ & $\begin{array}{c}\text { Approv } \\
\text { al } \\
\text { Rate }\end{array}$ & Mean & $\begin{array}{c}\text { Std. } \\
\text { Dev }\end{array}$ & $\begin{array}{c}\text { Approv } \\
\text { al } \\
\text { Rate }\end{array}$ & t & P \\
\hline $\begin{array}{c}\text { Planting } \\
\text { industry }\end{array}$ & 2.74 & 0.75 & $8.7 \%$ & 4.13 & 0.99 & $62.5 \%$ & 4.13 & $<0.001$ \\
\hline $\begin{array}{c}\text { Breeding } \\
\text { industry }\end{array}$ & 2.43 & 0.79 & $4.3 \%$ & 3.13 & 1.13 & $25.0 \%$ & 1.91 & 0.06 \\
\hline $\begin{array}{c}\text { Ecological } \\
\text { tourism }\end{array}$ & 4.35 & 1.07 & $87.0 \%$ & 4.63 & 0.52 & 100.0 & 0.70 & 0.49 \\
\hline $\begin{array}{c}\text { Transportation } \\
\text { and hydropower }\end{array}$ & 3.57 & 0.99 & $39.1 \%$ & 3.13 & 0.99 & $25.0 \%$ & 1.08 & 0.29 \\
\hline
\end{tabular}


Chengzhao Wu, Tianren Yang, Pei Pei \& Haisu Chen

Community Perception of Management Goals in Matoushan National Nature Reserve

As shown in Table 4, the community residents and managers have a common view regarding developing ecological tourism and their rates of approval are $87.0 \%$ and $100.0 \%$ respectively. Meanwhile, both community residents and managers hope to change current living state through developing tourism. As with other three projects, the community residents have a strong appeal for developing transportation and hydropower (the mean value is 3.57 and the rate of approval is $39.1 \%$ ) while the managers prefer to develop planting industry (the mean value is 4.13 and the rate of approval is $62.5 \%$ ) while hoping that traditional industries like farming will be continued in the nature reserve. During the survey, however, we got to know that the only a few community residents are engaging in farming and the per capita cultivated land is very small. Consequently, the community residents regard developing planting industry has little relation to their life quality. On the other hand, infrastructure, especially development of transportation, directly affects their degrees of contacting the outside world. Therefore, the community residents hope to benefit from developing infrastructure.

Table 5: Resident aiding projects regarding community co-management

\begin{tabular}{lcccccccc}
\hline Project Content & \multicolumn{3}{c}{ Residents } & \multicolumn{3}{c}{ Managers } & \multicolumn{2}{c}{ T-Test } \\
\cline { 2 - 9 } & Mean & $\begin{array}{c}\text { Std. } \\
\text { Dev }\end{array}$ & $\begin{array}{c}\text { Approv } \\
\text { al } \\
\text { Rate }\end{array}$ & Mean & $\begin{array}{c}\text { Std. } \\
\text { Dev }\end{array}$ & $\begin{array}{c}\text { Approv } \\
\text { al } \\
\text { Rate }\end{array}$ & t & P \\
\hline Direct funding & 4.26 & 0.86 & $82.6 \%$ & 4.50 & 0.76 & $87.5 \%$ & 0.69 & 0.49 \\
\hline $\begin{array}{l}\text { Technical } \\
\text { aiding }\end{array}$ & 3.00 & 1.09 & $26.1 \%$ & 4.00 & 0.54 & $87.5 \%$ & 2.48 & $<0.05$ \\
\hline $\begin{array}{l}\text { Preferential } \\
\text { policies }\end{array}$ & 3.87 & 0.87 & $65.2 \%$ & 4.25 & 1.04 & $87.5 \%$ & 1.02 & 0.32 \\
\hline
\end{tabular}

In addition to that, we can see from statistics of residents' preferences for aiding projects (Table 5) that both community residents and managers agree the form of direct funding (rates of approval are $82.6 \%$ and $87.5 \%$ respectively); as with technical information aiding $(\mathrm{t}=2.48, \mathrm{p}<0.05)$, the rate of approval of community residents is $26.1 \%$ only (that of managers is $87.5 \%$ ), which means the community residents prefer direct capital aiding and preferential policies.

\section{Expectation for Future Development of the Reserve}

Community residents and managers are greatly varying from each other regarding cognition of out-migration for work and immigration (moving out of the reserve) 
Table 6: Policies for developing the residents' life

\begin{tabular}{lcccccccc}
\hline Content & \multicolumn{3}{c}{ Residents } & \multicolumn{3}{c}{ Managers } & \multicolumn{2}{c}{ T-Test } \\
\cline { 2 - 10 } & Mean & $\begin{array}{c}\text { Std. } \\
\text { Dev } \\
\text { Rate }\end{array}$ & $\begin{array}{c}\text { Approv } \\
\text { Ran }\end{array}$ & $\begin{array}{c}\text { Std. } \\
\text { Dev }\end{array}$ & $\begin{array}{c}\text { Approv } \\
\text { al } \\
\text { Rate }\end{array}$ & t & P \\
\hline Immigration & 2.74 & 1.32 & $17.4 \%$ & 4.00 & 1.41 & $75.0 \%$ & 2.28 & $<0.05$ \\
\hline $\begin{array}{l}\text { Out-migration } \\
\text { for work }\end{array}$ & 3.52 & 1.20 & $47.8 \%$ & 2.38 & 1.06 & $12.5 \%$ & 2.39 & $<0.05$ \\
\hline $\begin{array}{l}\text { Engage in } \\
\text { tourism industry }\end{array}$ & 4.74 & 0.69 & $95.7 \%$ & 4.25 & 0.89 & $75.0 \%$ & 1.61 & 0.12 \\
\hline $\begin{array}{l}\text { Marketization } \\
\text { of planting }\end{array}$ & 2.26 & 1.05 & $13.0 \%$ & 3.63 & 1.19 & $75.0 \%$ & 3.06 & $<0.05$ \\
\hline $\begin{array}{l}\text { Maintain the } \\
\text { current state }\end{array}$ & 2.39 & 0.72 & $0.0 \%$ & 3.00 & 1.51 & $37.5 \%$ & 1.52 & 0.14 \\
\hline
\end{tabular}

Considering social and economic features of Matoushan NNR, this research has designed 5 policy scenarios for knowing the community residents' and managers' response (Table 6). According to sample statistics of responded residents, local residents' choices of different policy scenarios in terms of priority are: (1) engage in tourism industry (4.74); (2) out-migration for work (3.52); (3) immigration (2.74); (4) maintain the current state (2.39); (5) marketization of planting (2.26). According to sample statistics of responded managers, local managers' choices of different policy scenarios in terms of priority are: (1) engage in tourism industry (4.25); (2) immigration (4.00); (3) marketization of planting; (4) maintain the current state; (5) out-migration for work (2.38).

In comparison to immigration policy, local residents are more interested in engaging in tourism industry and out-migration for work, which is related to local residents' attained benefits or effect of the two policies. In Matoushan NNR, outmigration for work is the primary income source for local residents. Though tourism industry in this area is at the primary stage and the residents can only get limited income from it, they believe tourism has a promising prospect.

Furthermore, the statistical analysis indicates that the managers and residents are greatly varying from each other with regard to immigration $(\mathrm{t}=2.28, \mathrm{p}<0.05)$, outmigration for work $(t=2.39, p<0.05)$ and marketization of planting $(t=3.06, p<0.05)$. On one hand, the mangers hope to overcome the contradiction between protection and development in the reserve simply through immigration; on the other hand, they do not want a great deal of young people to work in other places because that will result in a shortage of labor in the county and appearance of a great deal of hollow villages. As with marketization of planting, managers of local forestry bureau and agricultural bureau prefer to develop economic crops and underwood industry so as to increase overall economic income of the county. For the community residents, however, they have little interest in incomes from developing agriculture since per capital cultivated land is small and the common farming way is self-sufficient. 
Chengzhao Wu, Tianren Yang, Pei Pei \& Haisu Chen

Community Perception of Management Goals in Matoushan National Nature Reserve

Most community residents and managers are holding an optimistic attitude towards participating in tourism development but local residents are generally unwilling to participate in tourism planning

Table 7: Expectations after the NNR is established

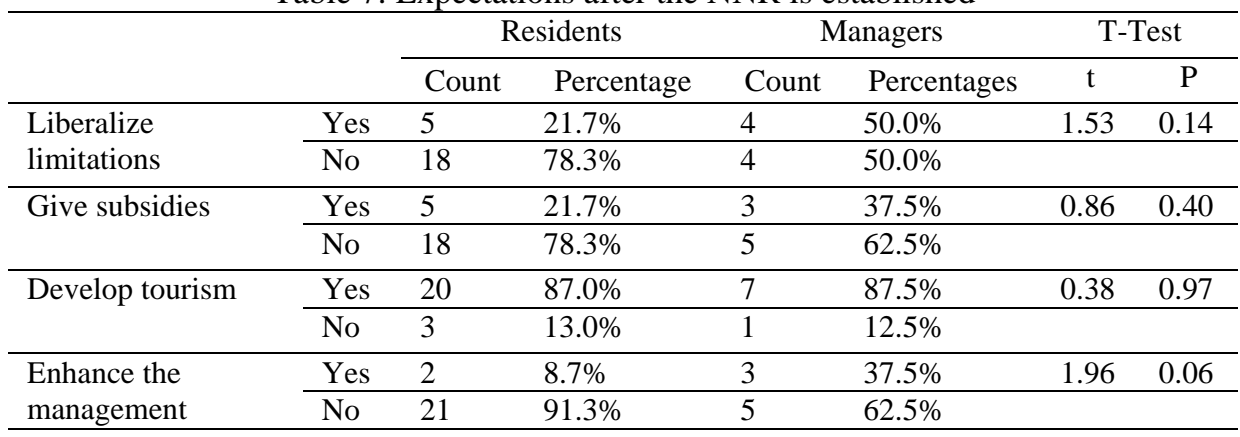

The statistical analysis indicates that the expectation of managers is not significantly related to that of community residents after the reserve is established (Table 7); the two parties hold similar attitudes towards liberalization of policies ( $\mathrm{t}=1.53$, $\mathrm{p}=0.14)$, giving subsidies $(\mathrm{t}=0.86, \mathrm{p}=0.40)$, developing tourism $(\mathrm{t}=0.38, \mathrm{p}=0.97)$ and enhancing the management $(\mathrm{t}=1.96, \mathrm{p}=0.06)$.

In the survey questionnaire on attitudes towards participating in developing tourism, 6 questions are presented for knowing the residents' and managers' attitudes and behaviors towards tourism development (as shown in table 9). The rating is positive, that is, unwilling is rated as 1 point, quite unwilling as 2 points, common or neutral 3 points, quite willing 4 points and very willing 5 points.

Table 8: Attitudes towards participating in tourism development

\begin{tabular}{lcccccccc}
\hline Content & \multicolumn{3}{c}{ Residents } & \multicolumn{3}{c}{ Managers } & \multicolumn{2}{c}{ T-Test } \\
\cline { 2 - 9 } & Mean & $\begin{array}{c}\text { Std. } \\
\text { Dev }\end{array}$ & $\begin{array}{c}\text { Approv } \\
\text { al } \\
\text { Rate }\end{array}$ & Mean & $\begin{array}{c}\text { Std. } \\
\text { Dev }\end{array}$ & $\begin{array}{c}\text { Approv } \\
\text { al } \\
\text { Rate }\end{array}$ & t & P \\
\hline $\begin{array}{l}\text { Participate in } \\
\text { tourism } \\
\text { development }\end{array}$ & 4.22 & 1.04 & $82.6 \%$ & 4.00 & 1.31 & $87.5 \%$ & 0.48 & 0.64 \\
\hline $\begin{array}{l}\text { Run tourist } \\
\text { reception } \\
\text { projects }\end{array}$ & 4.39 & 0.84 & $86.7 \%$ & 3.38 & 1.19 & $50.0 \%$ & 2.65 & $<0.05$ \\
\hline $\begin{array}{l}\text { Participate in } \\
\text { tourism } \\
\text { planning }\end{array}$ & 2.57 & 1.24 & $21.7 \%$ & 3.63 & 1.30 & $62.5 \%$ & 2.06 & $<0.05$ \\
\hline $\begin{array}{l}\text { Participate in } \\
\text { environmental } \\
\text { protection and } \\
\text { resource } \\
\text { management }\end{array}$ & 3.35 & 1.03 & $30.4 \%$ & 3.88 & 1.55 & $75.0 \%$ & 1.09 & 0.28 \\
\hline
\end{tabular}




\begin{tabular}{lcccccccc}
\hline $\begin{array}{l}\text { Hired by a } \\
\text { tourism } \\
\text { enterprise }\end{array}$ & 3.87 & 1.10 & $65.2 \%$ & 3.63 & 1.30 & $62.5 \%$ & 0.52 & 0.61 \\
\hline $\begin{array}{l}\text { Participate in } \\
\text { tourism } \\
\text { education and } \\
\text { training }\end{array}$ & 3.83 & 1.15 & $65.2 \%$ & 3.88 & 1.13 & $62.5 \%$ & 0.10 & 0.92 \\
\hline
\end{tabular}

From Table 8 , we can see that most of the community residents $(82.6 \%)$ and managers $(87.5 \%)$ hold a positive attitude towards engaging in tourism development. Among the community residents, $86.7 \%$ of them are willing to run some tourist reception projects and $65.2 \%$ are willing to be hired by a scenic area or tourism enterprise but only $21.7 \%$ are willing to participate in tourism planning and $30.4 \%$ are willing to participate in environmental protection and resource management. Therefore, the residents are greatly driven by economic benefits from tourism development; meanwhile, they have a low degree of perception of the importance of environment and do not realize that environment and resources constitute the foundation and precondition for developing tourism industry. In addition to that, the average point and approval rate of the education and training option are very high, which means the community residents have a strong desire for knowledge and skills.

In terms of running tourism projects $(\mathrm{t}=2.65, \mathrm{p}<0.05)$, the managers may hold that the phenomenon of hollow village is severe nowadays and there are no enough labors for running projects. However, the community residents hold that young people of their families will be willing to go back home for work as long as there are good job opportunities and economic benefits. As with participating in tourism planning $(\mathrm{t}=2.06$, $\mathrm{p}<0.05)$, the community residents have a very low degree of recognizing and participating in the planning and are not willing to actively participate in the planning compared with the managers.

\section{CONCLUSION AND ENLIGHTENMENT}

Development of a reserve is inseparable from life of local community residents. The managers' and community residents' different perception of goals of NNR management are likely to become the source of conflict between the reserve and community. This paper, through selecting community residents and managers as objects of survey respectively and observing their attitudes towards current living state in the reserve and response to relevant policies and future development of the reserve, has made an analysis of factors that affect the relationship between the reserve and community. On the other hand, response from local residents is established upon interaction between their benefits and goals as well as relevant policies of reserve management, so it can objectively reflect subjective wishes and objective facts and provide reference for future management of the reserve.

As a matter of fact, the inherent contradiction between the reserve and community can only be overcome in a real sense when an effective mechanism for promoting harmonious development of the reserve and community is found. In this way, the reserve management can be integrated with community development policies and sustainable development of the reserve. 
Chengzhao Wu, Tianren Yang, Pei Pei \& Haisu Chen

Community Perception of Management Goals in Matoushan National Nature Reserve

Establish a long-term and stable benefit-sharing mechanism for the nature reserve and community residents

While trying to improve economic development level, living conditions and education level of the community, the reserve should minimize negative impact on the community and encourage the community to serve the protection of biodiversity. Only in this way can the harmonious development between the reserve and community be achieved. For the residents in the reserve, therefore, a lack of an effective benefit compensation mechanism after establishment of the reserve is the objective basis for the contradiction and conflict between the reserve and community residents. The reserve can make use of favorable environmental foundation of the experimental area and peripheral zone to develop low-intensity and ecological secondary and tertiary industries so as to achieve industrial diversification and provide local community with subsidies.

Enhance public participation and achieve win-win of protection and development through multiple forms

As a beneficial exploration for nature reserve management model in China, community co-management gives full consideration to benefits of local government and community residents. It has displayed unique advantages. Community co-management can effectively arouse residents' enthusiasm to participate and establish an incentive mechanism that compels different stakeholders to actively participate in co-management so as to enhance self-development capacity of the nature reserve. In addition to that, considering that the residents have a low degree of cognition of community comanagement (17.3\%), the management department should strengthen the publicity of comanagement knowledge so as to enhance residents' consciousness of participating in protection and development of the reserve and enable local community and nature reserve to participate in the whole process of natural resource management, decision-making, implementation and evaluation.

\section{Apply multiple policies to increase job opportunities for local residents}

A lack of job opportunities in a nature reserve is likely to result in a great loss of labors in the county. Along with that young labors in the community have out-migrate for work, a great deal of "hollow villages" have been resulted in. Therefore, how to arrange production, life and work of the community residents should be a priority of the reserve. The reserve should get out of the dilemma of passive protection, make its due contributions for local economic construction and community development through establishing an industrial belt, increase job opportunities for local residents and properly coordinate the relationship between the community residents and resource protection.

\section{Implement targeted immigration policies step by step according to the goals of reserve management}

On the issue of moving community residents in the nature reserve, the managers hope to overcome the contradiction between protection and development once and for all through immigration. However, results of actual researches indicate that most of the community residents are not willing to leave their hometown. From the perspective of sustainable development of the reserve, it is infeasible to move the residents out of the reserve once 
for all. Local government can encourage some residents to develop outside the reserve through making policies and planning; moreover, the government should construct homestays outside the reserve. In this way, economic incomes of local residents can be improved through benefiting from ecological tourism industry and therefore their living conditions will be improved.

\section{Arouse enthusiasm of the residents to participate in construction and management of the reserve and develop eco-tourism}

The community residents in the reserve know well local society, culture, environment and resources and such information is very important for constructing and planning the reserve, resource investigations, environmental monitoring and evaluation as well as resource protection and utilization. Moreover, local residents can play a role of saving wages and costs for housing, transportation and construction of other service facilities in the process of constructing and managing the nature reserve and developing eco-tourism. Furthermore, some residents can be changed from relying and utilizing resource to engaging in resource management work so as to relieve pressure from local community on resource protection.

\section{DIRECTIONS FOR FUTURE RESEARCH}

In this paper, a preliminary research of harmonious development between eco-tourism development of Matoushan NNR and community benefits is made primarily through empirical research, literature analysis, field investigation, questionnaire survey, conversation with managers, expert interview and other ways. However, future perfection and in-depth researches of many areas are required.

i. Due to restrictions from time and relevant resources, this research has studied only representative communities while basing on community surveys and interviews. Since Matoushan NNR covers a wide area and communities are varying regarding states of protection and development, the selected survey villages and gathered data are inadequate to present state of the whole reserve. Future researches should enlarge the scope of survey and data collection and apply various methods for sample selection, survey, interview and data processing so as to further specify population characteristics of research objects, make in-depth analyses of the relationship between population characteristics of the residents and their willingness to participate and degrees of participation, study community residents' perception, attitudes and participation behaviors towards tourism in different places of the reserve, identify the law and influencing factors and make the researches feature with a higher degree of universality.

ii. In this research, the objects of investigation are community residents in the nature reserve and managers and there is a big deviation between effective recovered questionnaires from the community residents and managers. Researches in future should try to make the numbers of samples be close so as to make the analytical procedure be more scientific and the analytical conclusion be more persuasive.

iii. Through field investigation, department interview and questionnaire survey, the author has made some empirical research of the community residents and managers. However, the eco-tourism development of Matoushan NNR involves many interestrelated groups, such as tourists, developers and people who care for the reserve. 
Chengzhao Wu, Tianren Yang, Pei Pei \& Haisu Chen

Community Perception of Management Goals in Matoushan National Nature Reserve

Considering that, future researches can make a more in-depth and comprehensive investigation or analysis of more stakeholders so as to identify consensus and disagreement among different interest groups.

\section{REFERENCES}

Buchecker, M., Hunziker, M., \& Kienast, F. (2003). Participatory landscape development: Overcoming social barriers to public involvement. Landscape and Urban Planning, 64(1-2), 29-46.

Freeman, A.M., 1994. Depletable externalities and pigovian taxation. Journal of Environmental Economics and Management 11, 173-179.

Grimble, R., \& Wellard, K. (1997). Stakeholder methodologies in natural resource management: a review of principles, contexts, experiences and opportunities. Agricultural Systems, 55(2), 173-193.

Koorosh, S. S., Sza, I., \& Ahad, F. (2015). Evaluating Citizens' Participation in the Urban Heritage Conservation of Historic Area of Shiraz. Procedia - Social and Behavioral Sciences, 170, 390-400.

Price, M. F. (2002). The periodic review of biosphere reserves: a mechanism to foster sites of excellence for conservation and sustainable development. Environmental Science \& Policy, 5(1), 13-18.

Price, M. F., Park, J. J., \& Bouamrane, M. (2010). Reporting progress on internationally designated sites: The periodic review of biosphere reserves. Environmental Science \& Policy, 13(6), 549-557.

Reed, M. G., \& Egunyu, F. (2013). Management effectiveness in UNESCO Biosphere Reserves: Learning from Canadian periodic reviews. Environmental Science \& Policy, 25, 107-117.

Zhou, D., Wang, Z., Lassoie, J., Wang, X., \& Sun, L. (2014). Changing stakeholder relationships in nature reserve management: A case study on Snake Island-Laotie Mountain National Nature Reserve, Liaoning, China. Journal of Environmental Management, 146, 292-302.

Zhou, D. Q., \& Edward Grumbine, R. (2011). National parks in China: Experiments with protecting nature and human livelihoods in Yunnan province, Peoples' Republic of China (PRC). Biological Conservation, 144(5), 1314-1321. 